\title{
KERAMIIKKATAITEILIJA MAALARINA
}

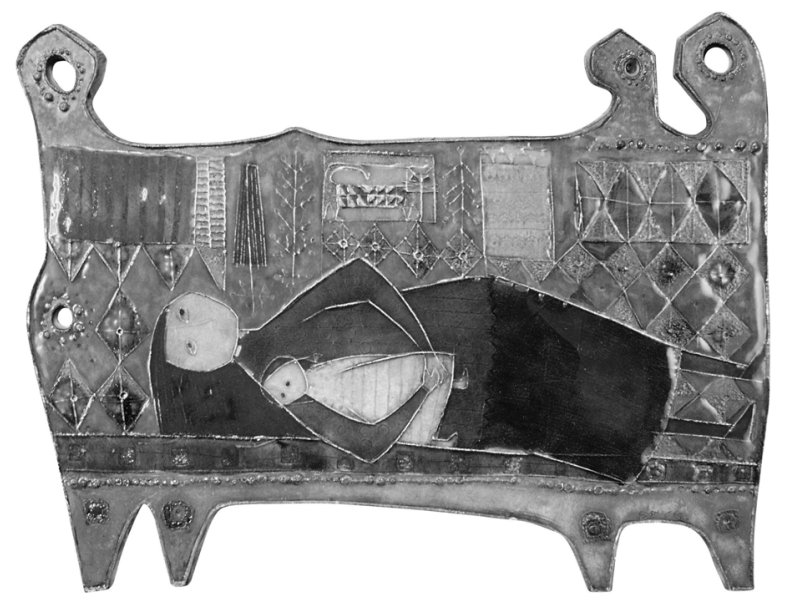

Rut Bryk: Tilkkutäkki, 1956, fajanssi ja värilasite, 500 x 570 mm. Valokuva: Erno Enkenberg.

Rut Bryk (1916-1999) on mielenkiintoinen luku suomalaisen modernin taiteen historiassa. Hän oli yksi ikäluokkansa kansainvälisesti menestyksellisimpiä taiteilijoita, mutta välineensä - keramiikan - ja ehkä osin sukupuolensakin tähden hän on jäänyt "eristyksiin”. En väitä, etteikö Bryk olisi saanut huomiota ja arvostusta. Päinvastoin sitä tuli hänen osakseen runsaasti sekä kotimaassa että ulkomailla. Minulla on kuitenkin vaikutelma, että Brykin töiden dialogi erityisesti aikalaistaiteen kanssa on yhä vailla luontevaa vastakaikua ja ymmärrystä.

Koulutukseltaan Bryk oli graafikko, jonka sattuman oikut johdattivat Arabian tehtaiden keramiikkataiteilijaksi 1940-luvun alussa. Taiteilijana hän itsenäistyi 1950-luvulla, kun hän otti pitkiä henkisiä loikkia sekä tekniikassa että taidenäkemyksessään. Arabian insinöörin Helge Forsbergin kanssa yhteistyössä Bryk kehitti laajan ja monipuolisen värilasituspaletin, joka antoi hänelle mahdollisuuden työskennellä taidemaalarin vapauksin. Samalla hän kasvoi yhä tietoisemmaksi sekä modernismin että Italian renessanssin taiteen historiasta ja käsitteellisistä lähtökohdista.

Modernisteista erityisesti Georges Braque merkitsi Brykille paljon. Ranskalaisen kubistin tapa pelkistää ja rakentaa sommitelma näyttää antaneen herätteitä esimerkiksi hänen Kannu ja sitruuna ja Hella -keramiikkateoksilleen vuonna 1950. Parhaimmillaan piirrosviivansa sujuvuudessa Bryk tuntuu ottaneen oppia myös toiselta ranskalaiselta modernistilta Henri Matisselta ja hellyttävässä lapsenomaisuudessaan Henri Rousseaulta, mutta kuten sveitsiläisen Paul Kleen taiteessa, myös suomalaisella naiivius yhdistyi älykkyyteen.

Keramiikkataiteilijan taito soveltaa kubismin perustavaa ideaa, simultaanista esitystapaa, teki hänen teoksistaan intensiivisiä ja kerroksellisia. Esimerkiksi Tilkkutäkki-työssä vuode on kuvattu keramiikkalaatan muotona, peite ja äiti ylhäältä päin ja lapsi kuten kissakin sivulta. Brykin Madonna ja Maaemo-teoksissa italialaisen renessanssitaiteen teemat ja kolorismi ovat saaneet arkaaisen tulkinnan poltetun saven ja lasituksen keinoin.

Brykin 1950-luvun teokset ovat keskustelusuhteessa luonnollisesti hänen opettajansa keramiikkataiteilija Birger Kaipiaisen työhön mutta myös monen kotimaisen aikalaismaalarin kuten Unto Koistisen, Heimo Riihimäen tai Kimmo Kaivannon taiteen kanssa. Vähitellen viimeistään 1960-luvun lopulla - arkkitehtoninen reliefimäisyys syrjäytti maalauksellisen painotuksen Brykin keramiikkataiteessa, mutta koko tuotantonsa ajan hän ammensi innoitusta myös maalaustaiteen kysymyksistä ja ilmaisusta. 